\title{
NONLINEAR DYNAMICAL ANALYSIS ON THE FORMATION OF CADMIUM OXIDE BY LASER DEPOSITION
}

\author{
D.A. Grado-Caffaro*, M. Grado-Caffaro \\ C/Julio Palacios 11, 9-B, 28029- Madrid (Spain) \\ *E-mail:ma.grado-caffaro@sapienzastudies.com \\ Received 3 October 2018, revised 30 October 2018
}

It is well-known that II-VI compounds occupy a very relevant place in the whole context of semiconductors. In particular, II-VI semiconductor and isolating or quasi-isolating oxides play an important role. Among these materials, we can mention zinc oxide and cadmium oxide. These oxides, which are transparent (at least in the visible range), are suitable for a number of optoelectronics applications. In this respect, let us consider solar cells; indeed, the above oxides serve as antireflection coatings for these cells. Cadmium oxide, doped or undoped, despite it is hazardous to manipulate, is certainly very interesting for the aforementioned optoelectronics applications. On the other hand, many aspects of this oxide may be regarded from the experimental and theoretical standpoints. In relation to the experimental side, several techniques are currently used to produce cadmium oxide. Among these experimental methods, one can mention metal evaporation, sputtering over a glass substrate, and laser deposition. Perhaps, laser deposition is more advanced and promising than the other techniques. In addition, the fact that laser is involved in this type of deposition gives rise to that the main aspects of the physics and chemistry of cadmium oxide are, say, enhanced. Really, the physics and chemistry of cadmium oxide constitute a significant issue. In order to examine accurately the principal physical mechanisms underlying the formation of cadmium oxide by laser deposition, an in-depth theoretical nonlinear study upon the above formation is presented in this article. As a matter of fact, taking into account that the molecules $\left(\mathrm{Cd}_{2}, \mathrm{O}_{2}, \mathrm{CdO}\right)$ in the chemical reaction which gives $\mathrm{CdO}$ are diatomic, the Morse potential is assumed to act upon the inter-nuclear axis of the molecules which, consequently, behave as quantum anharmonic (nonlinear) oscillators. In fact, associated with the corresponding chemical reaction, inelastic collision between a cadmium molecule and an oxygen one is considered to give rise to two molecules of cadmium oxide. We analyze carefully this collision from the quantum-mechanical point of view (we recall that the molecules in question behave as quantum anharmonic oscillators). From this molecular collision, energy loss is produced due to the laser action. The energy loss is calculated and, from this result, we deduce a mathematical condition to be obeyed for the size of anharmonicity by using a suitable parameter.

KEYWORDS: cadmium oxide, laser deposition, Morse potential, nonlinear study, energy loss

\section{НЕЛІНІЙНИЙ ДИНАМІЧНИЙ АНАЛІЗ ФОРМУВАННЯ ОКСИДУ КАДМІЮ ПРИ ЛАЗЕРНОМУ ОСАДЖЕННІ M.A. GRADO-CAFFARO, M. GRADO-CAFFARO C/Julio Palacios 11, 9-B, 28029-Madrid (Spain)}

Добре відомо, що сполуки II-VI займають дуже важливе місце в контексті напівпровідників. Зокрема, важливу роль відіграють II-VI напівпровідникові та ізоляційні або квазіізолюючі окисли. Серед цих матеріалів можна згадати оксид цинку та оксид кадмію. Ці оксиди, які є прозорими (принаймні в видимому діапазоні), підходять для ряду додатків для оптоелектроніки. У цьому відношенні давайте розглянемо сонячні батареї; дійсно, описані вище оксиди служать антивідбиваючим покриттям для цих батарей. Оксид кадмію, легований або нелегований, незважаючи на небезпечність використання, безумовно, дуже цікавий для вищезгаданих застосувань у оптоелектроніці. 3 іншого боку, багато аспектів використання цього оксиду можна розглядати 3 експериментальних та теоретичних точок зору. Що стосується експериментальної сторони, в даний час використовується декілька методів отримання оксиду кадмію. Серед цих експериментальних методів можна згадати випаровування металів, розпилення по скляній підкладці та лазерне осадження. Можливо, лазерне осадження $є$ найбільш просунутим і перспективним, ніж інші методи. Крім того, той факт, що лазер бере участь у даному виді осадження, породжує, скажімо, посилення основних аспектів фізики та хімії оксиду кадмію. Дійсно, фізика та хімія оксиду кадмію становлять значну проблему. Для точного вивчення основних фізичних механізмів, що лежать в основі утворення оксиду кадмію лазерним осадженням, в даній статті наведено поглиблене теоретичне нелінійне дослідження на вищезгадане формування. По суті, беручи до уваги те, що молекули $\left(\mathrm{Cd}_{2}, \mathrm{O}_{2}, \mathrm{CdO}\right)$ в хімічній реакції, що дає $\mathrm{CdO}, є$ двоатомними, передбачається, що потенціал Морзе діє на міжядерну вісь молекул, які, як наслідок, ведуть себе як квантові ангармонічні (нелінійні) осцилятори. Фактично непружні зіткнення молекули кадмію 3 киснем у відповідній хімічній реакції, утворюють дві молекули оксиду кадмію. Ми аналізуємо це зіткнення з квантово-механічної точки зору (нагадуємо, що розглянуті молекули ведуть себе як квантові ангармонічні осцилятори). У цьому молекулярному зіткненні втрата енергії виникає завдяки дії лазера. Розраховуючи енергетичні втрати з використанням відповідного параметру ми виводимо математичні умови, які відповідають ступеню нелінійності.

КЛЮЧОВІ СЛОВА: оксид кадмію, лазерне осадження, потенціал Морзе, нелінійне дослідження, енергетичні втрати

\section{НЕЛИНЕЙНЫЙ ДИНАМИЧЕСКИЙ АНАЛИЗ ФОРМИРОВАНИЯ ОКСИДА КАДМИЯ ПРИ ЛАЗЕРНОМ ОСАЖДЕНИИ \\ *M.A. GRADO-CAFFARO, M. GRADO-CAFFARO \\ C/Julio Palacios 11, 9-B, 28029-Madrid (Spain)}

Хорошо известно, что соединения II-VI занимают очень важное место во всем контексте полупроводников. В частности, важную роль играют полупроводниковые и изолирующие или квазиизолирующие оксиды II-VI. Среди этих материалов можно упомянуть оксид цинка и оксид кадмия. Эти оксиды, которые являются прозрачными (по крайней мере, в видимом 
диапазоне), подходят для ряда применений оптоэлектроники. В этом отношении рассмотрим солнечные элементы; Действительно, вышеуказанные оксиды служат в качестве антиотражающих покрытий для этих клеток. Оксид кадмия, легированный или нелегированный, несмотря на то, что он опасен для манипулирования, безусловно, очень интересен для вышеупомянутых применений оптоэлектроники. С другой стороны, многие аспекты этого оксида можно рассматривать с экспериментальной и теоретической точек зрения. В отношении экспериментальной стороны в настоящее время используется несколько методов получения оксида кадмия. Среди этих экспериментальных методов можно упомянуть испарение металлов, распыление на стеклянный субстрат и лазерное осаждение. Возможно, лазерное осаждение является более совершенным и перспективным, чем другие методы. Кроме того, тот факт, что лазер участвует в этом типе осаждения, приводит к тому, что основные аспекты физики и химии оксида кадмия, скажем, усиливаются. Действительно, физика и химия оксида кадмия составляют значительную проблему. Для точного изучения основных физических механизмов, лежащих в основе образования оксида кадмия путем лазерного осаждения, в этой статье представлено углубленное теоретическое нелинейное исследование вышеуказанного образования. На самом деле, принимая во внимание, что молекулы $\left(\mathrm{Cd}_{2}, \mathrm{O}_{2}, \mathrm{CdO}\right)$ в химической реакции, которая дает $\mathrm{CdO}$, являются двухатомными, предполагается, что потенциал Морса действует на межъядерную ось молекул, которые, следовательно, ведут себя как квантовые ангармонические (нелинейных) осцилляторов. На самом деле, связанный с соответствующей химической реакцией, неупругое столкновение между молекулой кадмия и кислородным, как полагают, приводит к образованию двух молекул оксида кадмия. Мы тщательно анализируем это столкновение с квантовомеханической точки зрения (напомним, что рассматриваемые молекулы ведут себя как квантовые ангармонические осцилляторы). Из этого молекулярного столкновения потери энергии возникают из-за действия лазера. Рассчитывая энергетические потери с использованием соответствующего параметра, мы выводим математические условия, которые соответствуют степени нелинейности.

КЛЮЧЕВЫЕ СЛОВА: оксид кадмия, лазерное осаждение, Морзе потенциал, нелинейные исследования, потери энергии

It is well-known that the Morse-potential model is certainly significant. As a matter of fact, anharmonic (nonlinear) vibrational behaviour of diatomic molecules can be modelled by the Morse-potential model. Nevertheless, to be diatomic is not a necessary condition to satisfy the Morse approach. Indeed, by the so-called united-atom model approximation (see, for example, ref.[1], the vibrational motion of some polyatomic molecules can be also modelled by the Morse approach. In the present article, diatomic molecules will be treated. In fact, under laser action (which produces anharmonicity represented here by the Morse model), we will regard a cadmium molecule colliding with an oxygen one so, by the involved chemical reaction, two molecules of cadmium oxide appear. In this context, we will consider the formation of $\mathrm{CdO}$ by laser deposition. In particular, we refer to pulsed-laser deposition [2,3]. By means of this experimental technique, crystalline thin films of high quality can be obtained $[2,3]$. However, these films can be also obtained by using other methods [4-8]. In the following, we will develop a theoretical-analytical formulation to study the formation of cadmium oxide by laser deposition. In this study, as we have said before, we will tackle the corresponding chemical reaction as a collision process between a cadmium molecule and an oxygen one to produce two molecules of cadmium oxide. These four molecules will be treated as quantum anharmonic oscillators after the Morse model. The energy lost from the above collision process will be examined as due to the laser action. This examination will be done by taking into account that the laser frequency is much larger than the fundamental frequency of the anharmonic Morse oscillator.

The aim of the present study is elucidating theoretically, for the first time, the main physical mechanisms underlying the formation of cadmium oxide by laser deposition. As we have said before, the chemical reaction relative to produce $\mathrm{CdO}$ will be treated as a molecular inelastic collision process involving quantum anharmonic (nonlinear) oscillators from the Morse-potential model. Due to that the spacing between adjacent levels of the quantized molecular energy is non-uniform, then there is energy lost due to the involved laser field as we will see later. This fact will be studied carefully. On the other hand, we wish to emphasize that the above non-uniformity arises from the anharmonicity of the lasing molecules in question.

\section{THEORETICAL FORMULATION}

First, let us assume a diatomic molecule under a one-dimensional Morse potential so that the potential energy is:

$$
V(x)=D\left\{1-\exp \left[-\alpha\left(x-x_{0}\right)\right]\right\}^{2}
$$

where $x$ is cartesian coordinate in the direction of the inter-nuclear axis of the molecule, $D$ denotes potential-energy depth, $x_{0}$ is the equilibrium position of the molecule, and $\alpha$ stands for a parameter related to the width of the potential.

The energy of the molecule is quantized. This energy consists of the energy eigenvalues of the corresponding nonrelativistic, time-independent, Schrödinger equation with formula (1) as follows:

$$
E_{n}=\hbar \omega\left(n+\frac{1}{2}\right)\left[1-\frac{\hbar \omega}{4 D}\left(n+\frac{1}{2}\right)\right],
$$

where $\omega$ designates the fundamental angular frequency of the associated anharmonic oscillator (the above molecule) and $n=0,1,2, \ldots$ is the corresponding vibrational quantum number. 
On the other side, the formation of cadmium oxide occurs as:

$$
\mathrm{Cd}_{2}+\mathrm{O}_{2} \rightarrow 2 \mathrm{CdO} \text {. }
$$

The molecules of reaction (3) are diatomic. We wish to consider the vibrational behaviour of these (lasing) molecules under the potential energy of eq.(1), which represents the laser action. The molecules in question behave as quantum anharmonic oscillators, that is, quantum nonlinear oscillators. By virtue of reaction (3), the $\mathrm{Cd}_{2}$ and $\mathrm{O}_{2}$ molecules collide inelastically. Before the collision, we suppose that the two molecules are in state $|n\rangle$. After they collide, two $\mathrm{CdO}$ molecules appear so that one of them goes to state $|n+1\rangle$ and the other molecule goes to state $|n-1\rangle$ (notice that, of course, $n \geq 1$ ). Consequently, under all the above conditions, we have:

$$
2 E_{n}-E_{n+1}-E_{n-1}=W,
$$

where $W$ is lost kinetic energy arising from the laser action. Notice that $W=0$ in the absence of laser (harmonic case; elastic collision).

By combining formulas (2) and (4), it follows:

$$
W=\frac{\hbar^{2} \omega^{2}}{2 D} .
$$

The laser energy is the corresponding photon energy $\hbar \Omega$, which equals $W$. On the other hand, one has that $\Omega>>$. Then, under these conditions and taking into account eq.(5), one gets:

$$
\hbar \omega>2 D \text {. }
$$

By defining the well-known anharmonic coefficient, namely, $\varepsilon=\hbar \omega /(4 D)$, from relation (6) we have that $\varepsilon>1 / 2$ which involves very strong laser fields.

\section{RESULTS AND DISCUSSION}

For the first time, we have found formulae (4), (5) and (6) as main results of our formulation, which is really unprecedented and consistent with experimental observations [2,3]. The fact that pulsed-laser deposition of cadmium oxide implies that the laser action originates anharmonicity is, certainly, a relevant issue. In effect, in the absence of a given laser field, harmonic (that is, linear) behaviour takes place. By contrast, in the presence of a laser field, anharmonic (that is, nonlinear) behaviour occurs. This is our case, in which the laser in question is strong enough (see expression (6)). On the other hand, we have shown clearly the relationship between the laser field and the Morsepotential model. In addition, we may claim that our methodology may be extrapolated to a wide enough variety of situations related to molecular collisions, which are primarily included in the context of quantum interactions (let us consider eq.(4)).

\section{CONCLUSION}

Significant transparent (at least in the visible range) II-VI semiconductors as, for instance, cadmium oxide and zinc oxide, exhibit attractive electronic and optical properties that should be investigated theoretically by means of mathematically powerful methods instead of computer simulations. In particular, cadmium oxide (undoped and heavily doped) presents very interesting features which can be modelled by employing accurate theoretical-analytical techniques. The present article is an example of this. Other examples related indirectly to our formulation at least from a strict mathematical-physics standpoint should be refs. [9-11].

M.A. Grado-Caffaro (D) https://orcid.org/0000-0002-9118-1649

\section{ORCID IDs}

\section{REFERENCES}

[1]. S.Y. Bhide and S. Yashonath, J. Phys. Chem. A. 106, 7130-7137 (2002), DOI: 10.1021/jp020101e

[2]. M. Yan, M. Lane, C.R. Kannewurf and R.P.H. Chang, Appl. Phys. Lett. 78, 2342 (2001), DOI: 10.1063/1.1365410

[3]. R.A. Ismail, B.G. Rasheed, E.T. Salm and M. Al-Hadethy, J. Mater. Sci.: Mater. in Electronics. 18, (2007) 1027, DOI 10.1007/s10854-007-9129-4

[4]. C. Sravani, K.T.R. Reddy and P.J. Reddy, Mater. Lett. 15, 356-358 (1993).

[5]. A.A. Dakhel, Curr. Appl. Phys. 11, 11-15 (2011), DOI: 10.1016/j.cap.2010.06.003

[6]. D.J. Seo, J. Korean Phys. Soc. 45, 1575-1579 (2004).

[7]. F.C. Eze, Mater. Chem. Phys. 89, 205-209 (2005).

[8]. T.K. Subramanyan, G. Venkata Rao, K.T.R. Reddy and S. Uthanna, Indian J. Eng. Mater. Sci. 10, 151-154 (2003).

[9]. V.E. Rodionov, I.N. Shnidko, A. Zolotovsky and S.P. Kruchinin, Mater. Sci. 31, 232-239 (2013).

[10]. M. Sugahara and S.P. Kruchinin, Mod. Phys. Lett. B. 15, 473-477 (2001).

[11]. A.V. Soldatov, N.N. Bogolyubov (Jr.) and S.P. Kruchinin, Condens. Matter Phys. 9, 1-9 (2006). 